GRASAS Y ACEITES 65 (3)

July-September 2014, e039

ISSN-L: 0017-3495

doi: http://dx.doi.org/10.3989/gya.0223141

\title{
Fatty acid composition and some physicochemical characteristics of Sterculia apetala seed oils
}

\author{
S. Herrera-Meza ${ }^{\mathrm{a}, \bowtie}$, A.J. Martínez ${ }^{\mathrm{b}}$, M.G. Sánchez-Otero ${ }^{\mathrm{c}}$, M.R. Mendoza-López ${ }^{\mathrm{d}}$, \\ O. García-Barradas ${ }^{\mathrm{d}}$, G.R. Ortiz-Viveros ${ }^{\mathrm{a}}$ and R.M. Oliart-Ros ${ }^{\mathrm{e}}$ \\ ${ }^{a}$ Instituto de Investigaciones Psicológicas, Universidad Veracruzana, México \\ ${ }^{\mathrm{b}}$ Centro de Investigaciones Biomédicas, Universidad Veracruzana, México \\ 'Instituto de Neuroetología, Universidad Veracruzana, México \\ ${ }^{\mathrm{d}}$ Unidad de Servicios de Apoyo en Resolución Analítica, Universidad Veracruzana, México \\ ${ }^{e}$ Unidad de Investigación y Desarrollo en Alimentos, Instituto Tecnológico de Veracruz, México \\ Corresponding author: soherrera@uv.mx
}

Submitted: 5 February 2014; Accepted: 5 May 2014

SUMMARY: In the tropical rain forests of southeastern Mexico, the use of Sterculia mexicana and Sterculia apetala seed oils for human and animal nutrition is common. However, the seeds contain cyclopropene fatty acids, whose consumption is related with beneficial as well as detrimental physiological effects. The aim of this study was to determine the fatty acid profile and the physicochemical characteristics of S. apetala seed oil and to evaluate the effect of roasting on both aspects. Cyclopropenoic fatty acids, sterculic acid and malvalic acid were identified in the natural and roasted seed oils. The major component in the seed oil was sterculic acid, as has been reported for Sterculia mexicana and Sterculia foetida. The roasting process modified some physicochemical properties and the fatty acid composition of the seed oil, particularly by decreasing its content of sterculic acid. To our knowledge, this is the first report on the fatty acid composition of S. apetala seed oil.

KEYWORDS: Cyclopropenoic Fatty Acids; Sterculia apetala; Sterculia mexicana; Sterculic acid

RESUMEN: Determinación de la composición de ácidos grasos y algunas características fisicoquímicas del aceite de semillas de Sterculia apetala. En zonas tropicales del sureste de México, el uso de semillas de Sterculia mexicana y Sterculia apetala es común para consumo humano y animal. Sin embargo, dichas semillas contienen ácidos grasos ciclopropenoicos, los cuales se les ha relacionado tanto con efectos fisiológicos beneficiosos como adversos para la salud. El objetivo de este estudio fue determinar el perfil de ácidos grasos y las características fisicoquímicas de la especie $S$. apetala, así como la evaluación del aceite sometido a un proceso de tostado. Se identificaron ácidos grasos ciclopropenoicos como el ácido estercúlico y malválico, en el aceite natural y tostado. Para las especies $S$. mexicana y $S$. foetida, el componente mayoritario en las semillas fue el ácido estercúlico. El proceso de tostado modificó algunas propiedades fisicoquímicas y la composción de los ácidos grasos, especificamente disminuyó el contenido de ácido estercúlico. Para nuestro conocimiento, este es la primera información publicada sobre la composición de los ácidos grasos de la especie $S$. apetala.

PALABRAS CLAVE: Ácido estercúlico; Ácidos grasos ciclopropenoicos; Sterculia apetala; Sterculia mexicana

Citation/Cómo citar este artículo: Herrera-Meza S, Martínez AJ, Sánchez-Otero MG, Mendoza-López MR, GarcíaBarradas O, Ortiz-Viverosa GR, Oliart-Ros RM. 2014. Fatty acid composition and some physicochemical characteristics of Sterculia apetala seed oils. Grasas Aceites 65 (3): e039. doi: http://dx.doi.org/10.3989/gya.0223141.

Copyright: (C) 2014 CSIC. This is an open-access article distributed under the terms of the Creative Commons Attribution-Non Commercial (by-nc) Spain 3.0 Licence. 


\section{INTRODUCTION}

The genus Sterculia comprises 300 species of trees that belong to the order Malvales, occurring mostly in tropical regions of the world. The most extensively studied among them is Sterculia foetida L., which is found from Eastern tropical Africa to North Australia (Mujumdar et al., 2000). Its leaves, roots and gum are used in herbal medicine as aperient, diuretic, anti-inflammatory, and as a central nervous system depressant (Chopra et al., 1992).

The species Sterculia mexicana (R. Br), locally known as "Castaño", and Sterculia apetala (Jacq.), locally known as "Bellota", "Castaña" or "Tepetaca", are found in the tropical rain forests of southeastern Mexico in the states of Veracruz, Tabasco, Oaxaca and Chiapas (Penington and Sarukhán, 2005). They are exotic deciduous trees, $30-40 \mathrm{~m}$ in height, with horizontal branches grouped in the top of the tree in S. mexicana, or distributed over the tree trunk in $S$. apetala. The leaves are palmated-lobulated, $15-50 \mathrm{~cm}$ long, and located in groups at the end of the branches. The flowers are yellow with red or purple stripes. The fruits are brown ( $S$. apetala) or redish (S. mexicana) follicles, $8-10 \mathrm{~cm}$ long, found in groups of $3-5$, that contain $10-15$ black seeds of $2.5 \times 1.5 \mathrm{~cm}$, each covered by orange stinging spicules. The seeds are boiled or roasted (to develop a nutlike or peanut butter-like aroma and taste) and used for human nutrition and as animal forage. In some areas, grounded seeds are used for chocolate flavoring (Benitez et al., 2004; Vazquez-Torres et al., 2010).

It has been reported that the oils extracted from plants from the order Malvales, Fabales and Sapindales naturally contain cyclopropene fatty acids (CPFA) which are unusual fatty acids containing a three member carbocyclic ring forming the center of their 18 and 17 carbon chains (Bao et al., 2003; Vickery, 1980). Sterculic acid [8-(2-octyl-1-cyclopropenyl) octanoic acid] (Figure 1A) and malvalic acid [7-(2-octyl-1-cyclopropenyl) heptanoic acid]
(Figure 1B) are CPFA that contain a highly strained and reactive cyclopropene ring in their carbon chains. They are present in variable amounts in these plants, the highest content being reported for Sterculia foetida seeds oil, where the sterculic acid content is around 55\% (Corl et al., 2001). In addition to its role as energy and carbon storage in seeds, it has been proposed that it may serve as a protective agent against fungal and insect attack (Schimid and Patterson, 1988). Moreover, various biological activities have been observed after sterculic acid administration in cell cultures and animal models, showing beneficial as well as adverse results. Some studies have demonstrated that sterculic acid provokes reductions in body weight and adiposity, improvements in glucose tolerance and attenuates hepatic inflammation (Gomez et al., 2003; Major et al., 2008; Ortinau et al., 2012), while others have suggested adverse effects on smooth muscle proliferation, reproductive function and growth, induction of hypercholesterolemia and liver damage, and carcinogenic effects when given at high doses to rats $(>1 \%$ ) (Mujumdar et al., 2000; Major et al., 2008; Lee et al., 1971; Look et al., 2004; Pawlowski et al., 1985). Some of these effects have been related to the ability of sterculic acid to inhibit stearoyl-CoA desaturase activity (SCD, also known as $\Delta 9$ desaturase), a central lipogenic enzyme catalyzing the synthesis of monounsaturated fatty acids, mainly oleate $(\mathrm{C} 18: 1)$ and palmitoleate $(\mathrm{C} 16: 1)$, by the $\mathrm{O}_{2}$-dependent desaturation of palmitate (16:0) and stearate (18:0) (Gomez et al., 2003). Our group has found that the administration of $S$. mexicana seed oil to spontaneously hypertensive rats reduces body weight, adiposity, and improves blood pressure, adiponectin and triglyceride levels (HerreraMeza et al., 2013).

Given the potential effects that the consumption of sterculic acid might have on lipid metabolism and the fact that there is no information about the fatty acid composition of Mexican Sterculiaceae, the purpose of this study was to determine the fatty acid profile and the physicochemical characteristics of

A)

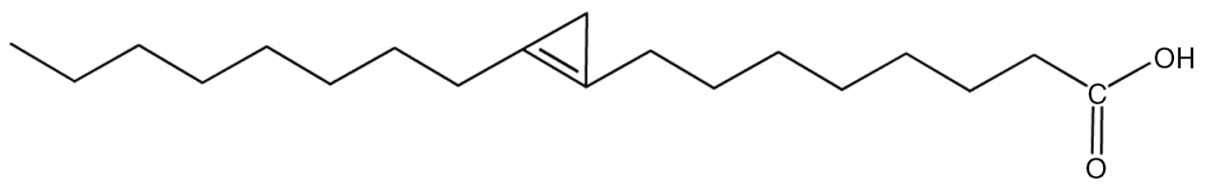

B)

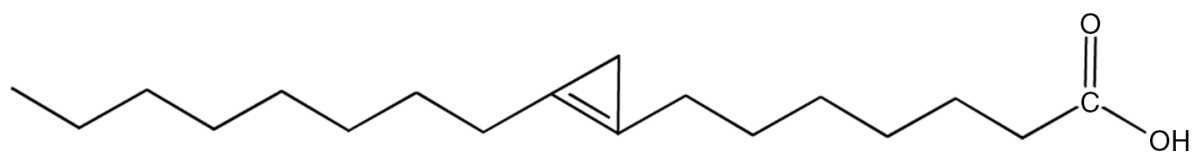

FIGURE 1. Chemical structures of: (A) sterculic acid (C19:1, [8-(2-octyl-1-cyclopropenyl) octanoic acid]) and (B) malvalic acid (C18:1, [7-(2-octyl-1-yclopropenyl) heptanoic acid]). 
S. apetala seed oil and to evaluate the effect of roasting on both aspects.

\section{MATERIALS AND METHODS}

\subsection{Sample collection}

Seeds from $S$. apetala were collected from two trees in Tolome $\left(19^{\circ} 16^{\prime} 0^{\prime \prime} \mathrm{N}, 96^{\circ} 23^{\prime} 41^{\prime \prime} \mathrm{W}\right.$, altitude $40 \mathrm{~m}$ ) in June and July. Results on fatty acid composition were compared to those previously found for S. mexicana (Herrera-Meza et al., 2013). Seeds from S. mexicana were collected from six trees found in Las Choapas $\left(17^{\circ} 15^{\prime} \mathrm{N}, 99^{\circ} 15^{\prime} \mathrm{W}\right.$, altitude $\left.115 \mathrm{~m}\right)$ in February and March. Both localities are located in the state of Veracruz, México. The seeds were stored at $4^{\circ} \mathrm{C}$ until further processing.

\subsection{Seed roasting procedure}

In order to analyze the effect of the roasting process, 1000 grams of Sterculia seed oil, S. apetala seeds were subjected to roasting in a pan exposed to stove heat, with a temperature of $140-150{ }^{\circ} \mathrm{C}$ for 20 min with occasional stirring, in a similar way as local people roast the seeds for their own consumption.

\subsection{Oil extraction}

Natural and roasted seeds were peeled manually and crushed in a mortar and their pulps were mixed with n-hexane for one week, at room temperature. The seeds to solvent ratio was $1: 3(\mathrm{~m} / \mathrm{v})$. The solvent was removed using a rotating evaporator at $50{ }^{\circ} \mathrm{C}$.

\subsection{Fatty acid analysis}

The fatty acids were derived according to Christie (Christie, 1982), using sodium methoxide and methyl acetate. Fatty acid methyl esters (FAME) were analyzed by gas chromatography (Hewlett Packard Model 61800B, GCD system with a capillary column polyethylene glycol, MW 20,000 (Carbo-Wax $20 \mathrm{M}$ ), $30 \mathrm{~m} \times 0.25 \mathrm{~mm} \times 0.25 \mu \mathrm{m}$, and mass spectrometry (Agilent Technologies 5975 inert $\mathrm{XL}$ model). The initial temperature was $150{ }^{\circ} \mathrm{C}$ for $5 \mathrm{~min}$, increased to $210^{\circ} \mathrm{C}$ at a rate of $30^{\circ} \mathrm{C} \cdot \mathrm{min}^{-1}$, then increased to $213{ }^{\circ} \mathrm{C}$ at a rate of $1{ }^{\circ} \mathrm{C} \cdot \mathrm{min}^{-1}$, finally increased to $225^{\circ} \mathrm{C}$ at a rate of $20^{\circ} \mathrm{C} \cdot \mathrm{min}^{-1}$ and held for $40 \mathrm{~min}$. Helium was used as a carrier gas, and mass spectra were obtained by electron-impact ionization at $70 \mathrm{eV}$. The identification of the peaks of each fatty acid was made by comparing the spectra with the GC library (HP-Chemstation NIST 05 Mass Spectral Research Program Version 2.0d) and with fatty acid standards (F.A.M.E mix, C8:C22, 18920-1AMP, Sigma-Aldrich) analyzed under the same conditions. The samples were analyzed in triplicate.

\subsection{Selected physicochemical properties}

Analyses of specific gravity, iodine value, acid value and saponification value of $S$. apetala natural and roasted seed oil were carried out using the standard methods (AOAC, 1990). The samples were analyzed in triplicate. Refractive index was determined on Abbe, Leica Mark II refractometer, model 10480 .

\subsection{Statistical analysis}

A separate, independent t-test was conducted for the comparison of fatty acid profiles between $S$. mexicana and $S$. apetala, a one sample $t$-test was used to compare these two species and t-test dependent samples (natural and roasted seed oil). We fitted the data into the software Statistica 7.0 (StatSoft, Inc. 1984-2004).

\section{RESULTS AND DISCUSSION}

The fatty acid composition of Sterculia apetala natural seed oil is shown in Table 1. The total ion current chromatogram of the FAMEs from Sterculia apetala (A) and Sterculia mexicana (B) is shown in Figure 2, and the respective mass spectra in Figure 3. The fatty acid profile was similar to those reported for S. foetida (Corl et al., 2001) and S. mexicana (Herrera-Meza et al., 2013) seed oils, so their fatty acid composition is included in tables for comparison purposes. As can be seen in Table 1, the major component in $S$. apetala and $S$. mexicana seed oil was sterculic acid (19:1 cyclo), the highest content was found in $S$. apetala $(56.3 \pm 0.91$ vs $51.3 \pm 0.29$ in $S$. mexicana, $\mathrm{p}<0.02 ;$ [ $9 \%$ higher]). The other CPFA, malvalic acid (18:1cyclo), was present in a minor proportion $(1.1 \pm 0.05$ in $S$. mexicana and $1.3 \pm 0.06$ in $S$. apetala). With respect to other fatty acids, the most abundant was palmitic acid (16:0) followed by oleic acid (18:1) and stearic acid (18:0). Minor but significant differences were found in oleic acid (C18:1) (8.8 \pm 0.09 in S. mexicana vs $9.5 \pm 0.16$ in $S$. apetala, $\mathrm{p}<0.04)$ and linoleic acid (C18:2) $(3.8 \pm 0.06$ in $S$. mexicana vs $2.9 \pm 0.11$ in $S$. apetala, $\mathrm{p}<0.01)$. Palmitic acid $(\mathrm{C} 16: 0)$ and stearic acid (18:0) percentages were found similar in both species (Table 1). In comparison to other Sterculia species, $S$. apetala and $S$. mexicana showed a high content of sterculic acid $(56.3 \%$ and $51.3 \%$ vs $11.3 \%$ in $S$. tormentosa, $30.2 \%$ in $S$. tragacantha, 5.3 in $S$. striata, $4 \%$ in $S$. alata, $5.8 \%$ in $S$. guttata, $3.2 \%$ in S. villosa), while a relatively low content was found for malvalic acid $(1.3 \%$ and $1.1 \%$ vs $5.8 \%$ in $S$. tormentosa, 5.1\% in S. tragacantha, 2.3 in S. striata, $17.6 \%$ in $S$. alata, $2.1 \%$ in S. guttata, $2.5 \%$ in $S$. villosa) (Miralles et al., 1993; Nitao et al., 2008; Badami et al., 1980). Conversely, the fatty acid profiles were more like those found in S. foetida seed oil 
TABLE 1. Fatty acid profiles of Sterculia mexicana and Sterculia apetala seed oils with the value of $\mathrm{t}$-test for the independent sample

\begin{tabular}{|c|c|c|c|}
\hline Fatty acid & S. mexicana* & S. apetala & t-test \\
\hline 16:0 & $21.8 \pm 0.18$ & $19.1 \pm 4.07$ & $\mathrm{t}=0.003, \mathrm{P}=0.9$ \\
\hline 18:0 & $8.5 \pm 0.13$ & $6.1 \pm 1.99$ & $\mathrm{t}=0.7, \mathrm{P}=0.5$ \\
\hline 18:1 & $8.8 \pm 0.09$ & $9.5 \pm 0.16$ & $\mathrm{t}=-4, \mathrm{P}=0.04$ \\
\hline 18:1 cyclo $^{\mathrm{a}}$ & $1.1 \pm 0.05$ & $1.3 \pm 0.06$ & $\mathrm{t}=-1, \mathrm{P}=0.40$ \\
\hline $18: 2$ & $3.8 \pm 0.06$ & $2.9 \pm 0.11$ & $t=9, P<0.01$ \\
\hline 19:1 cyclo $^{\mathrm{a}}$ & $51.3 \pm 0.29$ & $56.3 \pm 0.91$ & $t=-6, P<0.02$ \\
\hline Other & $4.4 \pm 0.26$ & $4.8 \pm 0.27$ & $\mathrm{t}=-1, \mathrm{P}=0.33$ \\
\hline
\end{tabular}

${ }^{a}$ Presence of cyclopropene ring. C18:1, malvalic acid [7-(2-octyl-1-yclopropenyl) heptanoic acid]; C19:1, sterculic acid [8-(2-octyl-1-cyclopropenyl) octanoic acid]. Values are expressed as mean \pm SE (percentage of total fatty acids). *Reported by Herrera-Meza et al., 2013.
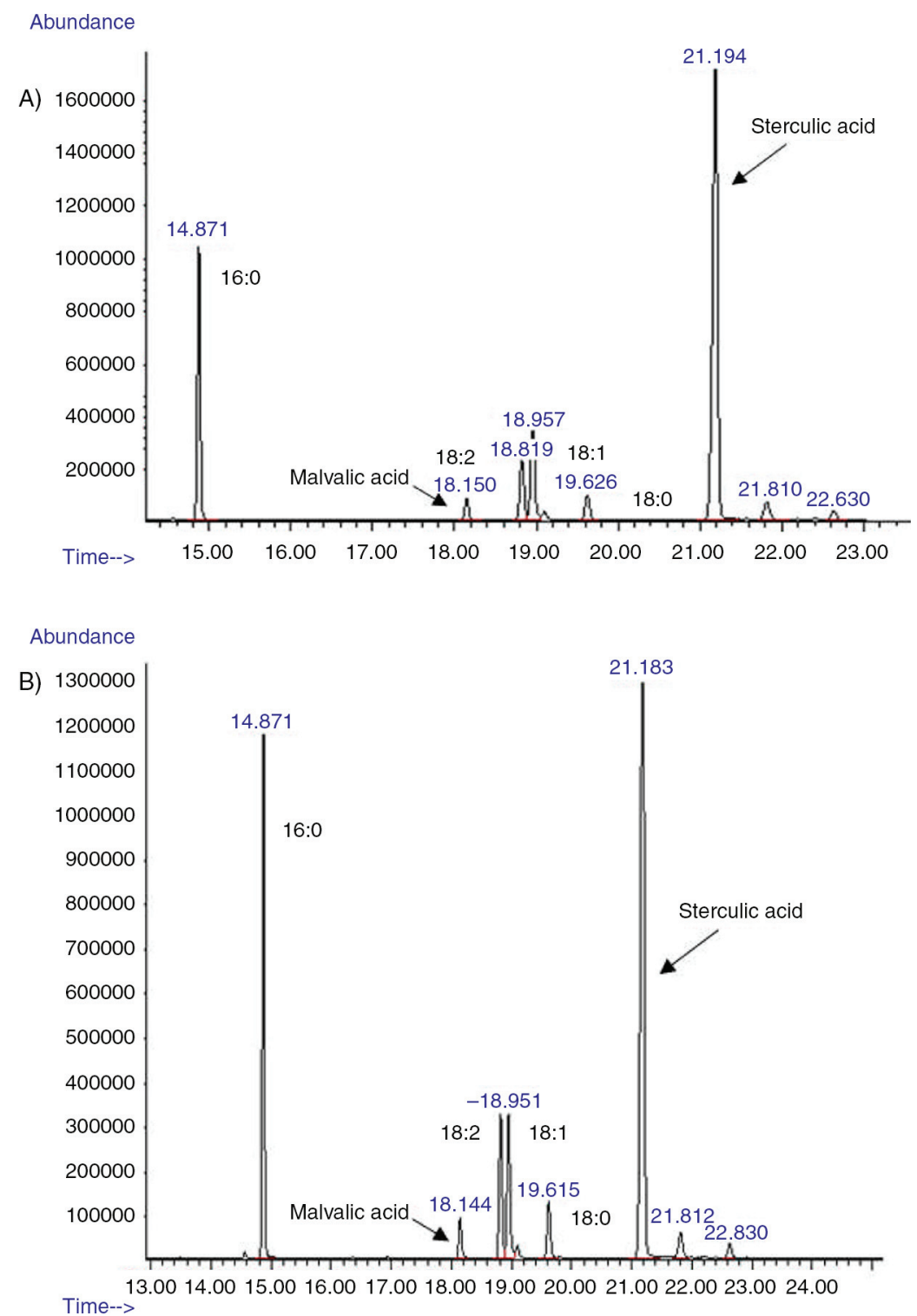

FIgURE 2. Total ion current gas chromatograms of the fatty acids profile of Sterculia apetala (A) and Sterculia mexicana (B). 
A)

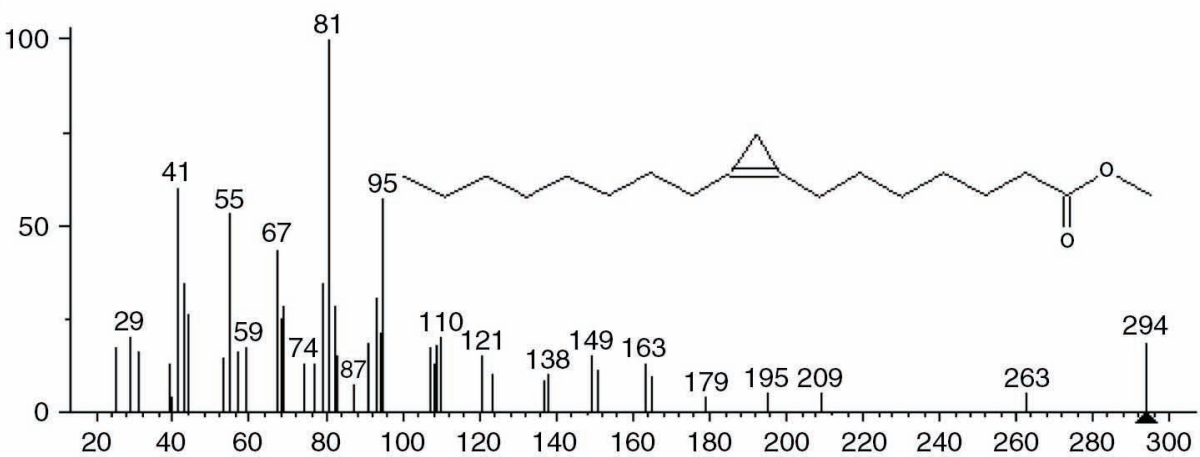

B)

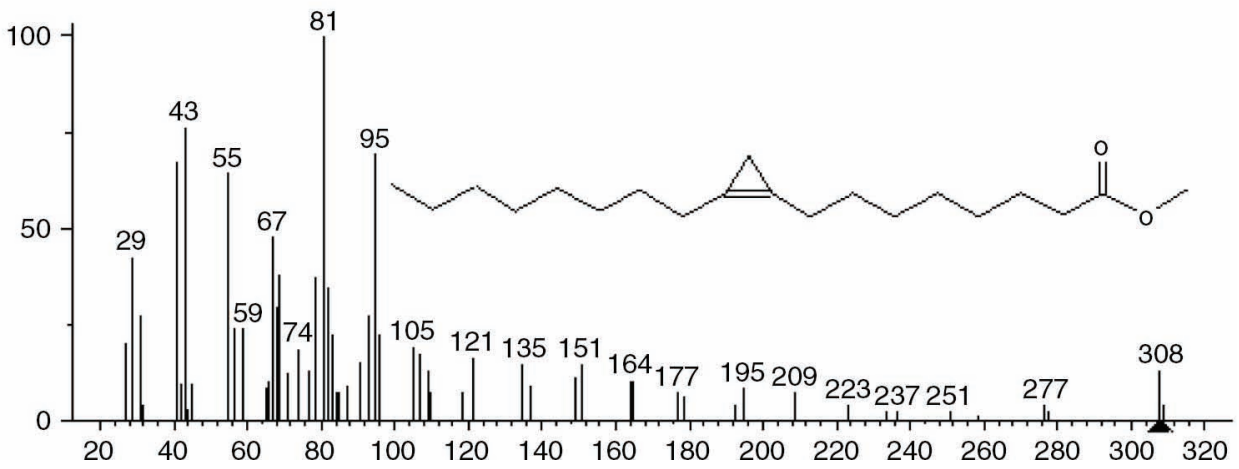

Figure 3. Mass spectra of sterculic acid from Sterculia apetala (A) and Sterculia mexicana (B) seed oil.

(Corl et al., 2001) (Table 2). With respect to CPFA, sterculic acid was found in similar proportions, although $S$. mexicana showed a significantly lower amount $(56.3 \pm 0.91$ in $S$. apetala, $51.3 \pm 0.29$ in $S$. mexicana vs 55.8 in $S$. foetida, $\mathrm{p}<0.03)$. S. mexicana and $S$. apetala showed a significantly lower amount of malvalic acid (18:1cyclo) (1.1 \pm 0.05 in $S$. mexicana [81\% lower], $1.3 \pm 0.06$ in $S$. apetala $[80 \%$ lower]

TABLE 2. Fatty acid profiles of Sterculia foetida seeds oils with the value of t-test for the simple sample

\begin{tabular}{|c|c|c|c|}
\hline Fatty acid & $\begin{array}{c}S . \\
\text { foetida }^{\mathrm{b}}\end{array}$ & $\begin{array}{c}\text { S. mexicana } \\
t \text {-test }\end{array}$ & $\begin{array}{c}\text { S. apetala } \\
\text { t-test }\end{array}$ \\
\hline 16:0 & 22.9 & $\mathrm{t}=-7, \mathrm{P}=0.08$ & $\mathrm{t}=-0.3, \mathrm{P}=0.7$ \\
\hline 18:0 & 1.8 & $t=71, P<0.01$ & $t=4, P=0.01$ \\
\hline $18: 1$ & 5.0 & $\mathrm{t}=59, \mathrm{P}<0.01$ & $\mathrm{t}=39, \mathrm{P}<0.01$ \\
\hline 18:1 cyclo $^{\mathrm{a}}$ & 6.3 & $\mathrm{t}=-146, \mathrm{P}<0.004$ & $\mathrm{t}=-126, \mathrm{P}<0.005$ \\
\hline $18: 2$ & 5.0 & $t=-31, P=0.02$ & $t=-26, P=0.02$ \\
\hline 19:1 cyclo $^{\mathrm{a}}$ & 55.8 & $t=-21, P=0.03$ & $\mathrm{t}=-0.4, \mathrm{P}=0.7$ \\
\hline Other & 2.8 & $\mathrm{t}=7, \mathrm{P}=0.08$ & $\mathrm{t}=9, \mathrm{P}=0.06$ \\
\hline
\end{tabular}

${ }^{\text {a}}$ Presence of cyclopropene ring. C18:1, malvalic acid [7-(2-octyl-1yclopropenyl) heptanoic acid]; C19:1, sterculic acid [8-(2-octyl-1cyclopropenyl) octanoic acid]. Values are expressed as percentage of total fatty acids.

${ }^{\mathrm{b}}$ Mean values of S. foetida reported by Corl et al., 2001. vs 6.3 in $S$. foetida, $<<0.004)$. A higher content of stearic acid (18:0) $(6.1 \pm 1.99$ in $S$. apetala, $8.5 \pm 0.13$ in $S$. mexicana vs 1.8 in $S$. foetida, $\mathrm{p}<0.01)$ and oleic acid (C18:1) (9.5 \pm 0.16 in $S$. apetala, $8.8 \pm 0.09$ in $S$. mexicana vs 5.0 in $S$. foetida, $\mathrm{p}<0.01$ ) were found in both Sterculia species, while the concentration of linoleic acid was lower than in S. foetida (C18:2) $(2.9 \pm 0.11$ in $S$. apetala, $3.8 \pm 0.06$ in $S$. mexicana vs 5.0 in S. foetida, $\mathrm{p}<0.02$ ) (Table 2).

The consumption of roasted Sterculia apetala seeds among the southeastern Mexican population is very common. Roasting is executed by a handmade process intended to develop a desirable flavor and aroma similar to peanut butter or nuts. We followed the procedure used by local people in order to analyze the effect of the roasting process on Sterculia apetala seed oil's fatty acid composition. It has been reported that heat destroys the inhibitory activity of sterculic acid over SCD (Gomez et al., 2003), and that vegetable edible oils containing CPFA need to be treated with high temperatures before consumption in order to avoid possible health problems (Bao et al., 2003). Results showed that roasting exerted important changes in the seed oil's fatty acid composition. Although sterculic acid was still the main component of the seed oil, its amount diminished by $36 \%$ with respect to the natural seed oil $(35.9 \pm 0.12$ in roasted seed oil vs $56.3 \pm 0.91$ in natural seed oil, 
TABLE 3. Fatty acid profiles of natural and roasted seed oil of Sterculia apetala with the value of t-test for the dependent sample

\begin{tabular}{lccc}
\hline Fatty acid & Natural seeds oil & Roasted seeds oil & t-test \\
\hline $\mathbf{1 6 : 0}$ & $19.1 \pm 4.07$ & $29.2 \pm 0.16$ & $\mathrm{t}=59.9, \mathrm{P}<0.0002$ \\
$\mathbf{1 8 : 0}$ & $6.1 \pm 1.99$ & $3.0 \pm 0.05$ & $\mathrm{t}=54.4, \mathrm{P}<0.0003$ \\
$\mathbf{1 8 : 1}$ & $9.5 \pm 0.16$ & $18.1 \pm 0.16$ & $\mathrm{t}=53.0, \mathrm{P}<0.0003$ \\
$\mathbf{1 8 : 1 \text { cyclo } ^ { \mathrm { a } }}$ & $1.3 \pm 0.06$ & $2.6 \pm 0.016$ & $\mathrm{t}=75.4, \mathrm{P}<0.0001$ \\
$\mathbf{1 8 : 2}$ & $2.9 \pm 0.11$ & $5.2 \pm 0.03$ & $\mathrm{t}=70.8, \mathrm{P}<0.0001$ \\
$\mathbf{1 9 : 1 \text { cyclo } ^ { \mathrm { a } }}$ & $56.3 \pm 0.91$ & $35.9 \pm 0.12$ & $\mathrm{t}=167.0, \mathrm{P}<0.00001$ \\
Other & $4.8 \pm 0.27$ & $5.9 \pm 0.024$ & $\mathrm{t}=48.9, \mathrm{P}<0.0004$ \\
\hline
\end{tabular}

${ }^{a}$ Presence of cyclopropene ring. C18:1, malvalic acid [7-(2-octyl-1-yclopropenyl) heptanoic acid]; C19:1, sterculic acid [8-(2-octyl-1-cyclopropenyl) octanoic acid]. Values are expressed as mean \pm SE of percentage of total fatty acids.

$\mathrm{p}<0.001)$. The content of malvalic acid was found to have increased by $96 \%(2.55 \pm 0.016$ in roasted seed oil vs $1.2 \pm 0.06$ in natural seed oil, $\mathrm{p}<0.001)$. We have found that the administration of natural seed oil from $S$. mexicana to spontaneously hypertensive rats provokes an inhibition of SCD activity (Herrera-Meza et al., 2013). Whether these modifications may cause a loss in the inhibitory activity of sterculic oil over SCD remains to be investigated. With the exception of stearic acid, the percentage of all the other fatty acids was increased after the roasting procedure (Table 3 ).

The physicochemical properties of $S$. apetala natural and roasted seed oil are shown in Table 4. The refractive index value of natural seed oil was similar to that reported for common oils such as soybean (1.4) (Bello et al., 2011), and was not modified by the roasting procedure. Specific gravity in the natural seed oil was found similar to other edible oils (Bello and Agg, 2012), and was increased after seed roasting. The iodine value is a measurement of the degree of instauration and reflects the susceptibility of oil

TABLE 4. Physicochemical parameters of Sterculia apetala natural and roasted seed oil

\begin{tabular}{lcc}
\hline Values & Natural oil & Toasted oil \\
\hline Color & Greenish yellow & Red \\
Refractive index & $1.46 \pm 0.0007$ & $1.46 \pm 0.0008$ \\
Specific gravity & $0.9 \pm 0.004$ & $1.4 \pm 0.07$ \\
Iodine value $\left(\mathrm{gI}_{2} \cdot 10 \mathrm{~g}^{-1}\right)$ & $45.7 \pm 1.27$ & $33.9 \pm 1.03$ \\
Acid value $\left(\mathrm{mg} \mathrm{KOH} \cdot \mathrm{g}^{-1}\right)$ & $79.4 \pm 0.86$ & $87.8 \pm 3.34$ \\
Saponification value $\left(\mathrm{mg} \cdot \mathrm{g}^{-1}\right)$ & $140.4 \pm 12.75$ & $159.3 \pm 8.49$ \\
\hline
\end{tabular}

Values are expressed as mean $\pm \mathrm{SE}$. to oxidation (Bello et al., 2011). The oil presented a low iodine value (45.7) which is in accordance with seed oil's fatty acid profile, mainly composed of saturated and monounsaturated fatty acids; it was found to have decreased after roasting (33.9). Since acid value is indicative of the content of free fatty acids in the oil, it is an important variable when considering the quality of oil: the lower the free fatty acids, the better the quality (Ibeto et al., 2012). According to the results, there are free fatty acids and triglycerides, methyl esters were obtained from both. S. apetala seed oil showed a very high acid value, both in natural $\left(79.4 \mathrm{mg} \mathrm{KOH} \cdot \mathrm{g}^{-1}\right)$ and in toasted $\left(87.8 \mathrm{mg} \mathrm{KOH} \cdot \mathrm{g}^{-1}\right)$ seed oil; however it could be minimized during refining of the oil. The saponification value is expressed as the number of milligrams of potassium hydroxide $(\mathrm{KOH})$ required to saponify $1 \mathrm{~g}$ of sample (Nayak and Patel, 2010). The saponification values of natural and roasted seed oil were 140.4 and 159.3 which indicates that the oil contains high molecular weight fatty acids on average. In consequence, this oil is not suitable for soap manufacturing.

In conclusion, the cyclopropenoic fatty acids, malvalic and sterculic acids were identified in Sterculia apetala seed oil in high amounts, similar to those found in Sterculia mexicana and Sterculia foetida. The roasting process modified the fatty acid composition of the seed oil; in particular a decrease in the content of sterculic acid was observed. It is noteworthy that $S$. mexicana and $S$. apetala seeds are commonly used in some tropical areas in Mexico for human and animal nutrition, so epidemiological studies are needed to determine possible health effects on the population. To our knowledge, this is the first report of the fatty acid composition of $S$. apetala seed oil. 


\section{ACKNOWLEDGMENTS}

The authors gratefully acknowledge the financial support provided by CONACyT, Mexico (No. 46764), PFA C-703/2013 AJM. The authors declare that they have no conflict of interest.

\section{REFERENCES}

AOAC. 1990. Official methods of analysis. 14th edn. Washington, DC: Association of Official Analytical Chemists.

Badami RC, Patil KC, Subbarao YV, Sastry GSR, Vihwanath Rao GK. 1980. Cyclopropenoid fatty acids of sterculia oils by gas liquid chromatography. Fette, Seifen. Anstrichm. 82, 317-318. http://dx.doi.org/10.1002/lipi.19800820806.

Bao X, Thelen JJ, Bonaventure G, Ohlrogge JB. 2003. Characterization of cyclopropane fatty acid synthase from Sterculia foetida. J. Biol. Chem. 278, 12846-12853. http:// dx.doi.org/10.1074/jbc.M212464200.

Bello EI, Agg M. 2012. Biodiesel production from ground nut oil. J. Emerging Trends in Engineering and Appl. Sci. 3, 276-280.

Bello MO, Lorine TL, Adeoyea DO, Oladimejib AO. 2011. Physicochemical properties and fatty acids profile of seed oil of Telfairia occidentalis. Int. J. Eng. Sci. 11,9-14.

Benitez BG, Pulido-Salas MT, Equihua M. 2004. Arboles multiusos nativos de Veracruz para reforestación, restauración $y$ plantaciones. Instituto de Ecología, A. C., SIGOLFO, CONAFOR eds. Xalapa, Veracruz, México, pp. 230-233.

Chopra RN, Nayar SL, Chopra IC. 1992. Glosary of indian medicinal plants. pp. 234, Publication and Information Directorate, CSIR, New Delhi.

Christie WW. 1982. A simple procedure for transmethylation of glycerolipids and cholesterol esters. J. Lipid Res. 23, 1073-5.

Corl BA, Baumgard LH, Dwyer DA, Griinari JM, Phillips BS, Bauman DE. 2001. The role of $\Delta-9$ desaturase in the production of cis-9, trans-11 CLA. J. Nutr. Chem. 12, 622-630.

Gomez EF, Bauman DE, Ntambi JM, Fox BG. 2003. Effects of sterculic acid on stearoyl-CoA desaturase in differentiating 3T3L1 adipocytes. Biochem Bioph Co 300, 316-326. http:// dx.doi.org/10.1016/S0006-291X(02)02842-5.

Herrera-Meza MS, Mendoza-López MR, García-Barradas O, Sanchez-Otero MG, Silva-Hernández ER, Angulo JO, Oliart-Ros RM. 2013. Dietary anhydrous milk fat naturally enriched with conjugated linoleic acid and vaccenic acid modify cardiovascular risk biomarkers in spontaneously hypertensive rats. Int. J. Food Sci. Nutr. 64, 574-586. http://dx.doi.org/10.3109/09637486.2013.763908.

Ibeto CN, Okoye COB, Ofoefule AU. 2012. Comparative Study of the Physicochemical Characterization of Some Oils as Potential Feedstock for Biodiesel Production. Renew Energ Article ID 621518.
Lee DJ, Wales JH, Sinnhuber RO. 1971. Promotion of aflatoxininduced hepatoma growth in trout by methyl malvalate and sterculate. Cancer Res. 31, 960-63.

Lock AL, Corl BA, Barbano DM, Bauman DE. 2004. The anticarcinogenic effect of trans-11 18:1 is dependent on its conversion to cis-9, trans-11 CLA by $\Delta 9$-desaturase in rats. $J$. Nutr. 134, 2698-2704.

Major CA, Ryan K, Bennett AJ, Lock AL, Bauman DE, Salter AM. 2008. Inhibition of stearoyl CoA desaturase activity induces hypercholesterolemia in the cholesterol-fed hamster. J. Lipid Res. 49, 1456-1465. http://dx.doi.org/10. 1194/jlr. M700596-JLR200.

Miralles J, Bassene E, Gaydou EM. 1993. Determination of cyclopropenoid fatty acids in Sterculia seed oils from Senegal. J. Am. Oil Chem. Soc. 70, 205-206. http://dx.doi. org/10.1007/BF02542627.

MujumdarAM, Naik DG, Waghole RJ, Kulkarni DK, Kumbhojkar MS. 2000. Pharmacological studies on Sterculia foetida leaves. Pharm. Biol. 38, 13-17. http:// dx.doi.org/10.1076/1388-0209(200001)3811-BFT013.

Nayak BS, Patel KN. 2010. Physicochemical characterization of seed and seed oil of jatrophacurcas l. collected from Bardoli (South Gujarat) (Ciri-ciri Fizikokimia Biji dan Minyak Biji Jatropha curcas L. diambil dari Bardoli (Selatan Gujarat)) Sains Malays 39, 951-955.

Nitao DZ, Singh BP, Queiroga NV, Oliveira CJM. 2008. Sterculia striata seed kernel oil: characterization and thermal stability. Grasas Aceites 59, 68-73.

Ortinau LC, Pickering RT, Nickelson KJ, Stromsdorfer KL, Naik CY, Haynes RA, Bauman DE, Rector RS, Fritsche KL, Perfield JW. 2012. Sterculic oil, a natural scd1 inhibitor, improves glucose tolerance in obese ob/ ob mice. ISRN Endocrinol. 2012, 947323. http://dx.doi. org/10.5402/2012/947323.

Pawlowski NE, Hendricks JD, Bailey ML, Nixon JE, Bailey GS. 1985. Structural-bioactivity relationship for tumor promotion by cyclopropenes. J. Agric. Food Chem. 33, 767-770. http://dx.doi.org/10.1021/jf00064a052.

Penington TD, Sarukhán J. 2005. Arboles tropicales de México para la identificación de las principales especies. Universidad Nacional Autónoma de México. Dirección general de publicaciones y fomento editorial, eds. México, D.F, pp 384-385.

Schmid KM, Patterson GW. 1988. Effects of cyclopropenoid fatty acids on fungal growth and lipid composition. Lipids 23I, 248-252. http://dx.doi.org/10.1007/BF02535466.

Vázquez Torres M, Armenta Montero S, Campos Jiménez J, Carvajal Hernández CI. 2010. Árboles de la región de los Tuxtlas. Library Congress QK211, ISBN 978-607-33-0007-0.

Vickery JR. 1980. The fatty acid composition of seeds oils from the plant families with particular reference to cyclopropene and dihydrosterculic acids. J. Am. Oil Chem. Soc. 57, 87-91. http://dx.doi.org/10.1007/BF02674370. 